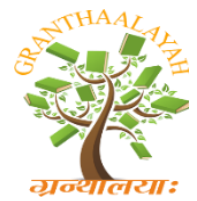

\author{
INTERNATIONAL JOURNAL OF RESEARCH - \\ GRANTHAALAYAH \\ A knowledge Repository
}

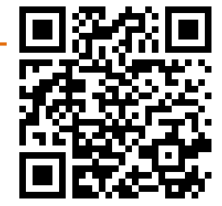

Science

\title{
ASSESSMENT OF CAUSE OF HULUKA MICRO HYDRO POWER SCHEME FAILURE AND ESTIMATION OF ITS POTENTIAL
}

\section{Tibebu Tsegaye Zigale ${ }^{* 1}$, Teressa Negassa Muleta ${ }^{1}$, Mubarek Jemal Mohammed ${ }^{1}$}

${ }^{1}$ Department of Hydraulic and Water Resources Engineering, Institute of Technology, Ambo University P.O Box 19, Ambo, Ethiopia

\begin{abstract}
In Ethiopia, several Micro hydropower (MHP) schemes were constructed between the year 1950 and 1970. One of the Micro hydropower schemes constructed within this period was Huluka Micro-hydropower. However, it is no longer operational nowadays due to some issues and problems. Hence, this research study aimed to assess the causes of failure and estimating the potential power of Huluka micro hydropower. The overall existing condition of the components of the Micro hydropower plants evaluated as to functionality and its physical measurements, including the identification of the potential factors responsible for the failure of the Micro hydropower. From the flow duration curve of Huluka River, it indicated a maximum and the minimum potential power of the scheme of about $1313.23 \mathrm{kw}$, and $274.41 \mathrm{~kW}$, respectively. Hence, it is postulated that rehabilitation of Huluka MHP could provide a solution to the current shortage and interruption of power supply in Ambo town as well as its surrounding areas.
\end{abstract}

Keywords: Cause of Failure; Flow Duration Curve; Micro Hydropower; Rehabilitation.

Cite This Article: Tibebu Tsegaye Zigale, Teressa Negassa Muleta, and Mubarek Jemal Mohammed. (2019). "ASSESSMENT OF CAUSE OF HULUKA MICRO HYDRO POWER SCHEME FAILURE AND ESTIMATION OF ITS POTENTIAL.” International Journal of Research - Granthaalayah, 7(8), 292-300. 10.29121/granthaalayah.v7.i8.2019.672.

\section{Introduction}

The demand for energy is growing throughout the world as energy is the backbone of the growth of a nation. A combination of increasing population growth rate, desire for an improved standard of living, and public policy have increased interest in green energy sources. Reliable access to electricity is basic preconditioning to improve people's lives in rural and urban areas, for enhanced health care, education, and for growth within local economies [1].

In East Africa, Ethiopia has a reasonably high-installed capacity of $80 \mathrm{MW}$ of stand-alone microand pico-hydropower plants [2]. This gives the opportunity to supply the base-load electricity to the main industrial locations and the city of capital Addis Ababa and export the remaining to the neighboring countries which can boost the country's earnings from foreign export. Ethiopia used 
different energy sources such as geothermal, hydropower, biomass, wind- power, gasoline, and diesel.

Electricity supply in Ethiopia is extremely antiquated. When compared to the African average, overall electric access in Ethiopia is very low. As in most Sub-Saharan Africa countries, urban access and rural access have a huge gap. With the per capita electricity consumption of $37 \mathrm{kWh}$ per year, Ethiopia has one of the lowest consumption rates worldwide. Only approximately $15 \%$ of populations have access to the power grid, about $89.6 \%$ of electricity in Ethiopia consumed in the urban area. The livelihood of $85 \%$ of the Ethiopian population is dependent on natural resources (particularly non-renewable natural resources). For instance, the study by the Central Statistical Agency (CSA) at the country level, suggests that about $81.4 \%$ of the households use firewood, around $11.5 \%$ cook with leaves and dung cakes and only $2.4 \%$ used kerosene for cooking. The majority of rural households used firewood (84.4\%), and few of them (12.7\%) use leaves and dung cakes [3].

In recent times due to this, the non-renewable and exhaustible sources of energy are getting depleted at a very fast rate, (forests, woodlands and generally biomass) is shrinking rapidly. This has called global attention to the non-exhaustible and renewable sources of energy. The topography of Ethiopia is well suited to the use of micro-hydropower. There are mountainous areas with many small rivers that are convenient for the development of small and micro-hydro power generation. The potential for small- and micro-hydropower development is estimated to be 1,5003,000 MW. It is limited by the seasonality of rainfall and reduced availability of water. When it comes to Micro and Pico-hydro power, the effect of seasonal on availability is very high. Hence, the total potential for Micro and Pico-hydro power (of size less $500 \mathrm{~kW}$ ) is estimated to be 100 MW (Muluken, 2014; [4]).

So far, out of the total potential for Micro hydropower plants in the country, only less than $1 \%$ is developed. Most of the potential sites are located in the Western and South Western parts of the country with varying from place to place depending on mean annual rainfall received by the area [4]. Countrywide the rainfall varies along the year; the minimum is $7.1 \mathrm{~mm}$ in January and maximum in August 133mm as per the world bank data from 1901 to 2009 (World bank 2018). In Ethiopia, several MHP schemes were installed in the period between 1950 and 1970 (Muluken, 2014). During this period EEPCo installed 1.5 MW. However, almost all of them are not operational now a day. One of the several MHP schemes found in Ethiopia which was installed in the period between 1950 and 1970 is Huluka Micro-hydropower, commissioned in 1954. It used to serve the community with an installed capacity of 150KW. The scheme did not function in 1967 as per the interview was done with that time guard of the scheme. This brought the socioeconomic problem of the town and its surrounding. In addition, schools, hospitals, government, and nongovernment institutes can't get adequate and continuous electricity supply. The inadequacy and discontinuity of electricity contributed much as investors do not invest in the vicinity of the town.

The majority of previous studies focus on the economic feasibility of rehabilitating Huluka microhydro power, but this study aimed at assessing the cause of failure of previously installed Huluka micro hydropower. The study also evaluates the status of the components of the existing scheme, identifies the factors responsible for the failure of the scheme, and the potential of the existing micro-hydropower scheme. Surveying and observational approach are used to gather the data 
necessary to describe the overall existing condition of the components of the MHP functionality, particularly the existing condition is explored by making some required physical measurements to access the data and information about the scheme readily.

\section{Study Area and Methods}

\subsection{Description of the Study Area}

The site of the Huluka Micro hydropower scheme is found along the Huluka river at the back of Ambo University, main campus, extending from $08^{\circ} 59^{\prime} 20.4^{\prime \prime} \mathrm{N}$ and $37^{\circ} 52^{\prime} 02^{\prime \prime} \mathrm{E}$, with an average elevation of 2,022 meters above sea level.

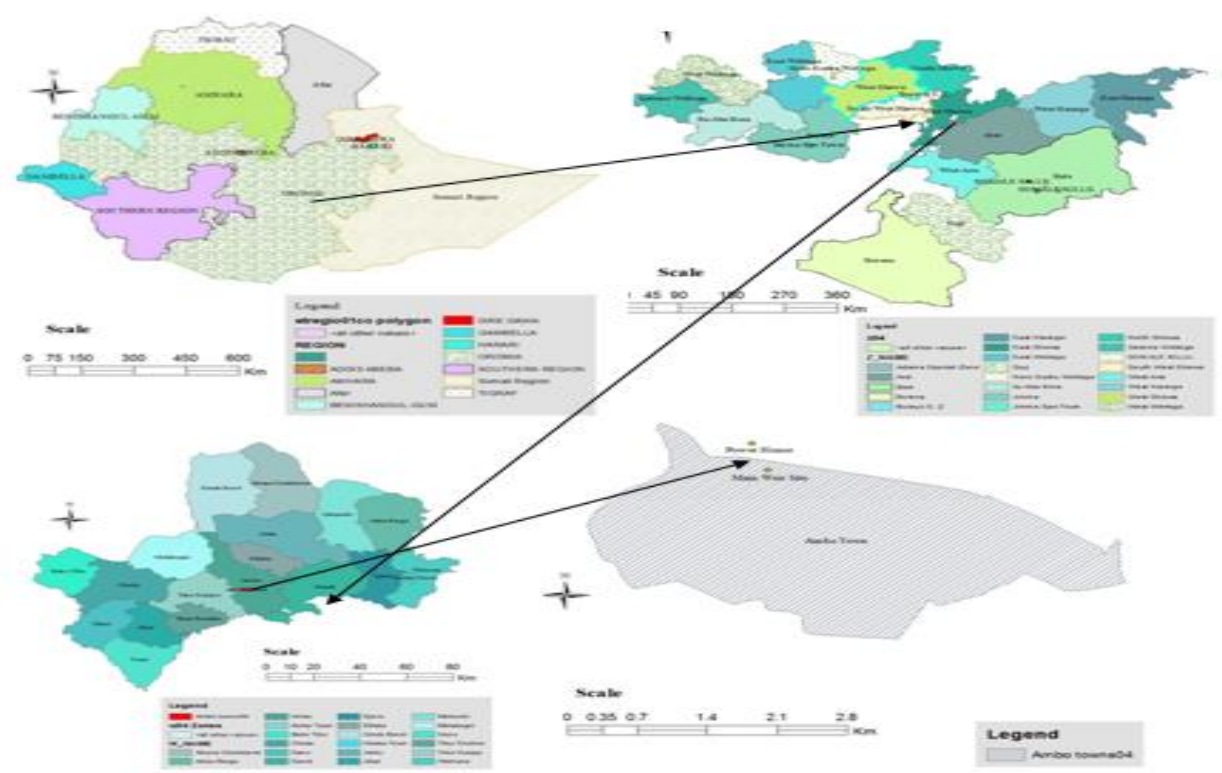

Figure 1: Location of the study area, from Arc GIS software.

\subsection{Data Collection Methods}

In this study, the experience with operational and non-operational schemes such as Gobecho I and II, which are non-functional micro-hydro power, were shared. After physical observation of those stations, both government offices, as well as non-government organizations concerned with the scheme, were interviewed. GPS and total station instruments used to collect geographical and elevation of the main component points to find and locate them on Google Maps.

Surveying and observation conducted to collect the data necessary to describe the overall existing condition of the components of the Micro hydropower (MHP). The existing condition explored by making some required physical measurements to access the data and information about the scheme readily. All major parts of the scheme, main Diversion weir, Aprons, retaining wall, Intake gate, Headrace Canal, settling basin, forebay, Penstock, Powerhouse, Tailrace, Turbine, Generator, control board evaluated. From here, the functional and non-functional components of the scheme are identified. In addition, interview and reconnaissance observational study in the study area were performed to identify factors responsible for the scheme failure. 


\subsection{Data Analysis}

The potential of the existing Micro-hydropower scheme was estimated. Twelve (12) years of instantaneous daily Huluka river flow was obtained from the Ministry of Irrigation Water and Electricity (MOIWE). This data was converted to annual flow basis for the construction of Flow duration curve(FDC) from which the percentage of time a discharge found at a different time of the year. The head of the scheme was obtained directly from a survey conducted. The technical or theoretical potential power of the scheme at variable discharge is calculated. There were identified a number of visible factors for the non-operation of the scheme that affects the operation of the Micro-hydropower. In the figure below, it shows the existing weir and components of Huluka river micro-hydropower.

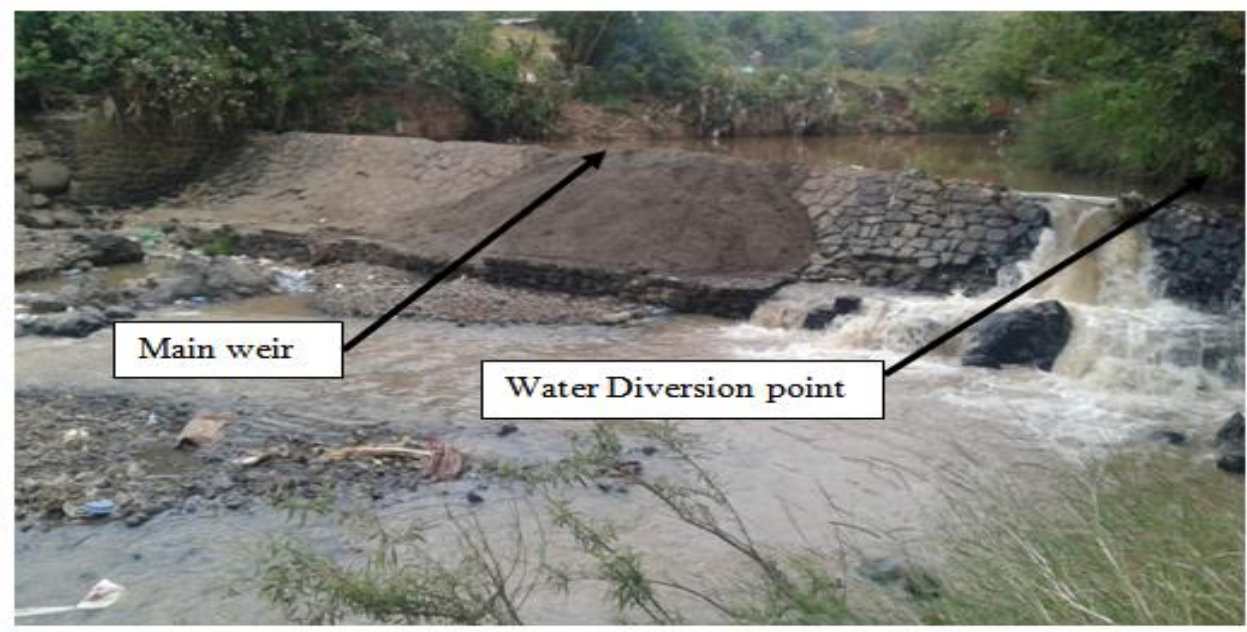

Figure 2: Photo was taken at the downstream side of the Main weir structure
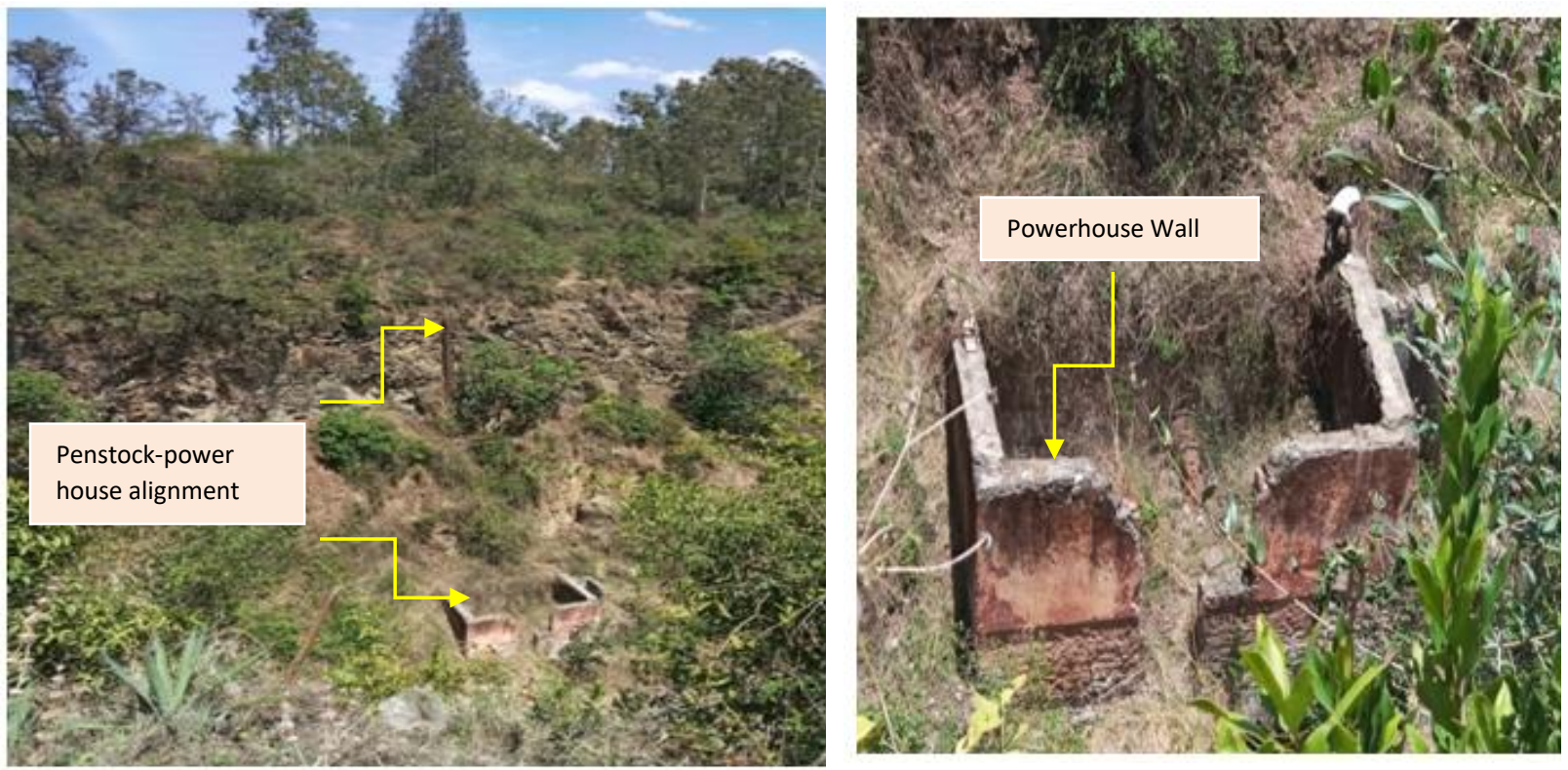

Figure 3: Showing Existing Penstock-Power House Alignment 

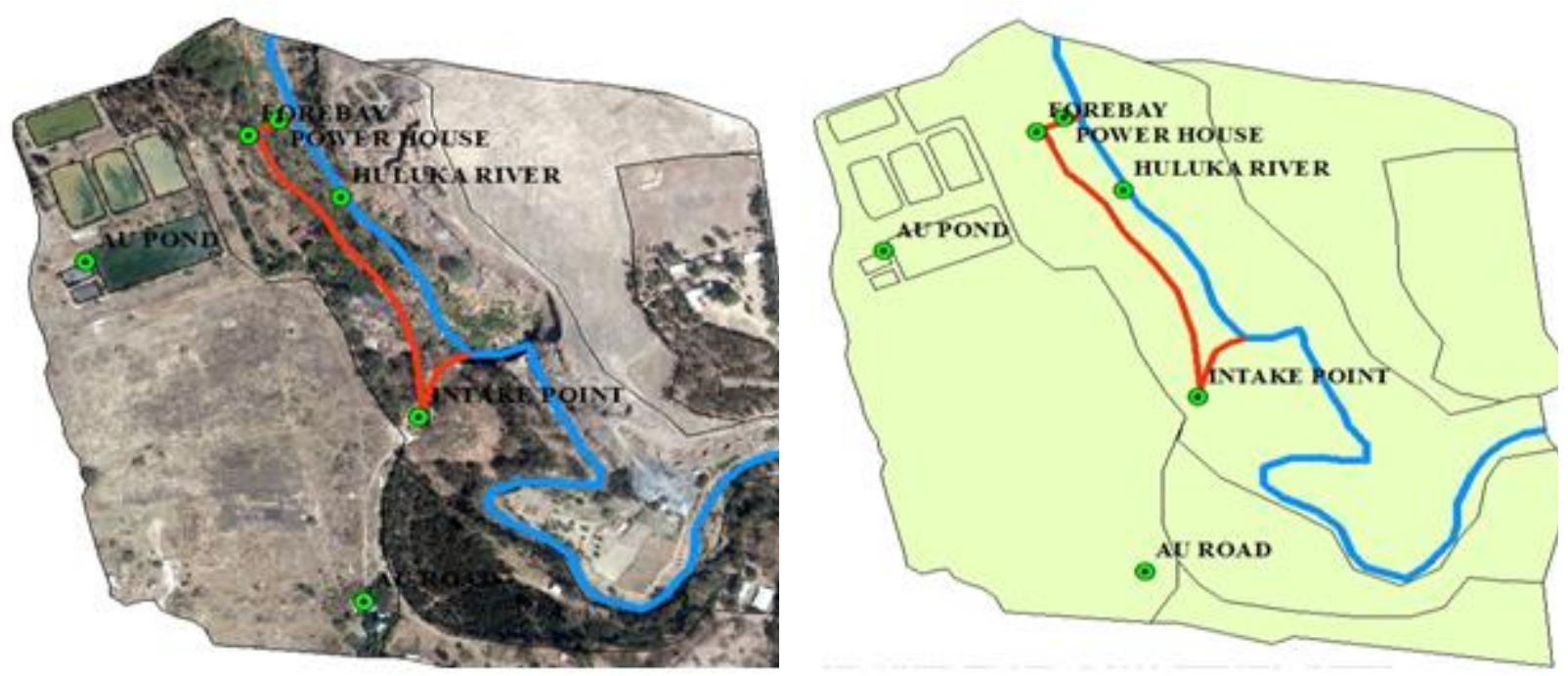

Figure 4: Google Maps showing Huluka river, the Micro-hydropower main components (intake, headrace, forebay, and powerhouse)

\section{Results and Discussion}

\subsection{Existing Conditions of the Main Weir Body}

The existing condition of all components of a Huluka micro hydropower scheme was assessed. The researchers found that the main Weir Body made of a masonry structure, with a height of $1.24 \mathrm{~m}$, and a top width of $20.15 \mathrm{~m}$. The Apron provided upstream and downstream of the main weir to protect the diversion weir foot, and heel from Scouring. Also, the Apron extension of the weir axis to the downstream side measured of about $3.7 \mathrm{~m}$, and $0.7 \mathrm{~m}$ layered thickness, which was observed in good condition and still functional except in a few sections partially scoured. The retaining wall of length $4.7 \mathrm{~m}$ extended from the axis of the weir to downstream side, a height of $2.9 \mathrm{~m}$ and a top width of $1.4 \mathrm{~m}$ found on the right and the left side wing of the Wier in which it is untouched and functional. At the point of water diversion, the head regulator and the Sluice gate installed side by side. However, it was sad to note that their openings clogged by debris, while the steering wheel at the top and shatter gates cutaway no longer existed. So the steering wheel and shatter steel plate should be replaced. The sluice gate has a height of $3.6 \mathrm{~m}$ and an opening of $0.7 \mathrm{~m}$. It's bottom lower than the crest of the main gate, which has a dimension of $3 \mathrm{mx} 0.8 \mathrm{~m}$. So now the water is spilling over the weir, and no water enters the headrace canal. The headrace canal constructed of both concrete and masonry. Headrace floor and wall are both lined and unlined one with a length of about $1.5 \mathrm{~km}$, the width of $1 \mathrm{~m}$, and a depth of about $1 \mathrm{~m}$. Its alignment, like most other micro-hydro schemes, runs along the side of the Huluka, and its route is clearly visible except parts of it are buried due to construction cutaway soil and wastes dumped along the canal. The canal almost silted up, some parts of its vegetation grown, filled with sidewall collapse and mass sliding and falling into the canal. As a result, not operational and major rehabilitation required.

On the other hand, the Forebay has a length of about $7.3 \mathrm{~m}$, the net width of $0.75 \mathrm{~m}$ and a depth of $2.3 \mathrm{~m}$, fully exist. The control gate, which controls the water entering to the forebay has a dimension of $2.8 \mathrm{mx} 0.85 \mathrm{~m}$. A trash rack with a dimension of $1.55 \mathrm{~m}$ length, $1.0 \mathrm{~m}$ width, $0.025 \mathrm{~m}$ thread spacing between horizontal arranged bars found at the end of the forebay that is at the inlet to the penstock, 
inclined at an angle of 54 degrees $\left(54^{\circ}\right)$ to the head of the penstock to prevent logging and debris not entered to the penstock. Penstock made of steel has a length of $50.44 \mathrm{~m}$ and diameter of $0.58 \mathrm{~m}$. It is normal except rust on the surface as seen externally and can be set into operation easily with no much cost. The powerhouse is made of a wall from brick materials, partly by concrete and partly by masonry with a wall height $4 \mathrm{~m}$ and width of $7 \mathrm{~m}$. The powerhouse is not being easily accessible as the way from forebay to the powerhouse is too steep and risky. The powerhouse floor is varied, walls collapsed and have no roof. Electro-mechanical components such as turbine, generator power control board and other related accessories are totally removed, and the only power shaft that is fixed to the penstock has existed. So the electromechanical part needs major maintenance and replacement. Tailrace exists, but its outlet is buried and needs maintenance. Generally, some of the scheme components such as weir, forebay, trash rack, and penstock can be set into function with maintenance, whereas the remaining components need redesign and replacement.

\subsection{Cause of the Scheme Failure}

The cause of failure of Huluka micro hydropower was assessed with the following methodologies;

\subsubsection{Interviews with Elders and Related Offices}

The results of the interview indicated that the Huluka micro hydropower could be omitted the scheme and shifting to grid electricity supply of Ambo town.

\subsubsection{Project Site Physical Observation and Analytical Test for Hydraulic and Structural Fitness of The Different Components}

The different measurements, like crest elevations, dimensions, slopes, head, and discharge, have been measured and checked the hydraulic and structural sufficiency. Accordingly, the team identified different engineering defects that had possibly caused the scheme failure. One was the absence of upstream wingwalls or retaining walls, particularly on the left-hand side (intake side) of the diversion structure that could have caused a mass sliding and the closure of the intake structure as shown in the photo below. Similarly, on the left-hand side of the headrace canal, the topography was too steep, in which it should have been retained thoroughly. In addition, the team has observed that Huluka River is known to carry much sediment during the rainy season and sufficient settling basin should have been included in the scheme for further desiltation as it could have possibly clogged the system. Another observation was the absence of the powerhouse roofing. The powerhouse is located in the river course, and due to overflowing on top, it caused damaged and failure of the electromechanical components of the scheme. Furthermore, the damping of excavated materials during constructions in the university might have changed the topography of the canal route as one of the contributory factors of the problem. 

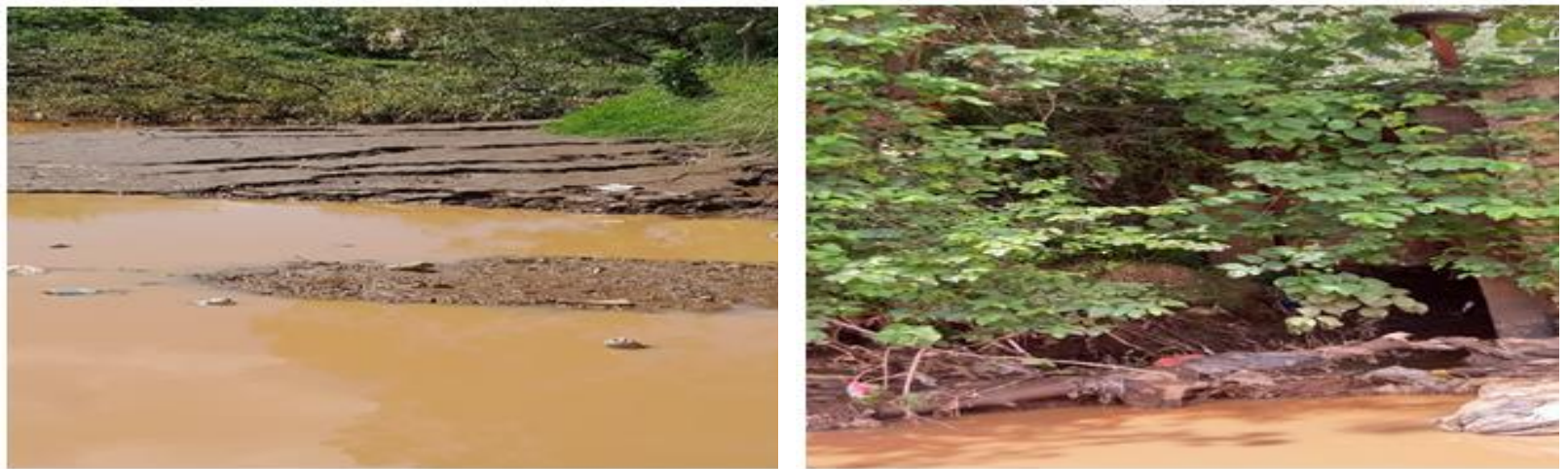

Figure 5: Siltation and erosion at upstream of the intake.

\subsubsection{Association of A Cause of Similar Schemes' Failure in The Country}

The team assessed similar schemes in the country, particularly those available in Southern Nations and Nationalities Region such as Gebicho 1 and 2, Eererte, and Abasamuel. With the information gathered and experience shared over these structures, the major and the common cause of failure for the schemes were social factors, lack of belongingness and poor management and maintenance.

\subsection{Potential Assessment of Huluka River}

Different potential or theoretical power of the Huluka river micro-hydropower depends on two main parameters, flow and head of the river estimated. The Flow Duration Curve is drawn, and from the curve, the discharge determined out of the different time percentage within the year. The head obtained from a survey made, used for the estimation of potential power. Flow measurement method applied in this research based on the instantaneous daily streamflow from data of eleven years taken from MOIWE and converted to mean annual flow to draw FDC. Within this year of gauged data, the maximum annual average flow indicated 7.812 cumecs. Head measurement with GPS method was not used during the investigation rather than the head measurement method applied using a total station to measure head. The forebay to powerhouse was $37.13 \mathrm{~m}$ with a gross head weir/intake to the powerhouse was about 40m. Likewise, the estimated maximum theoretical potential power comprised of $1313.23 \mathrm{KW}$. The table below shows the mean monthly flow of Huluka river from 1997 to 2008 Ethiopian Calendar (EC).

Table 1: Mean monthly flow of Huluka River

\begin{tabular}{|l|l|l|l|l|l|l|l|l|l|l|l|l|}
\hline Year (EC) & Jan & Feb & Mar & Apr & May & Jun & Jul & Aug & Sep & Oct & Nov & Dec \\
\hline 1997 & 0.489 & 0.37 & 0.526 & 0.276 & 0.094 & 0.25 & 2.199 & 2.631 & 0.8 & 0.356 & 0.244 & 0.103 \\
\hline 1998 & 0.213 & 0.142 & 0.337 & 0.525 & 0.978 & 0.732 & 10.752 & 22.671 & 4.781 & 0.961 & 0.636 & 0.432 \\
\hline 1999 & 0.452 & 0.41 & 0.785 & 0.786 & 1.69 & 3.039 & 23.319 & 47.438 & 9.356 & 5.458 & 0.486 & 0.523 \\
\hline 2000 & 0.58 & 0.55 & 0.448 & 0.559 & 0.43 & 0.817 & 2.458 & 32.023 & 8.164 & 2.131 & 0.96 & 0.057 \\
\hline 2001 & 0.513 & 0.427 & 0.412 & 0.29 & 0.664 & 1.904 & 7.791 & 16.607 & 6.972 & 1.211 & 0.484 & 0.311 \\
\hline 2002 & 0.445 & 0.304 & 0.383 & 0.311 & 0.281 & 0.543 & 4.023 & 12.575 & 1.631 & 0.787 & 0.739 & 0.748 \\
\hline 2003 & 0.961 & 0.361 & 0.244 & 0.448 & 0.298 & 0.627 & 9.617 & 8.025 & 2.448 & 0.309 & 0.302 & 0.294 \\
\hline 2004 & 0.683 & 0.269 & 0.293 & 0.443 & 0.273 & 0.996 & 4.474 & 10.247 & 1.904 & 0.206 & 0.053 & 0.054 \\
\hline 2005 & 0.405 & 0.038 & 0.185 & 0.543 & 0.814 & 0.991 & 7.188 & 9.668 & 6.348 & 0.763 & 0.355 & 0.349 \\
\hline 2006 & 0.396 & 0.478 & 0.419 & 0.514 & 0.587 & 5.729 & 10.019 & 13.391 & 3.974 & 0.199 & 0.113 & 0.108 \\
\hline 2007 & 0.169 & 0.29 & 0.26 & 0.716 & 1.077 & 4.429 & 12.66 & 7.757 & 3.459 & 1.321 & 0.03 & 0.009 \\
\hline 2008 & 0.005 & 0.005 & 0.005 & 0.218 & 1.078 & 2.888 & 23.025 & 21.892 & 4.869 & 1.086 & 0.96 & 0.101 \\
\hline
\end{tabular}


Table 2: Mean annual flow of Huluka River

\begin{tabular}{|c|c|c|c|c|}
\hline Year & $\begin{array}{c}\text { Mean Flows } \\
\text { (Cumecs) }\end{array}$ & $\begin{array}{c}\text { Flow Descending } \\
\text { Order (Cumecs) }\end{array}$ & Rank (M) & \% of Time Exceeded or Equaled \\
\hline 1997 & 0.695 & 7.812 & 1 & 8.333 \\
\hline 1998 & 3.597 & 4.678 & 2 & 16.667 \\
\hline 1999 & 7.812 & 4.098 & 3 & 25 \\
\hline 2000 & 4.098 & 3.597 & 4 & 33.333 \\
\hline 2001 & 3.132 & 3.132 & 5 & 41.667 \\
\hline 2002 & 1.898 & 2.994 & 6 & 50 \\
\hline 2003 & 1.995 & 2.681 & 7 & 58.333 \\
\hline 2004 & 1.658 & 2.304 & 8 & 66.667 \\
\hline 2005 & 2.304 & 1.995 & 9 & 75 \\
\hline 2006 & 2.994 & 1.898 & 10 & 83.333 \\
\hline 2007 & 2.681 & 1.658 & 11 & 91.667 \\
\hline 2008 & 4.678 & 0.695 & 12 & 100 \\
\hline
\end{tabular}

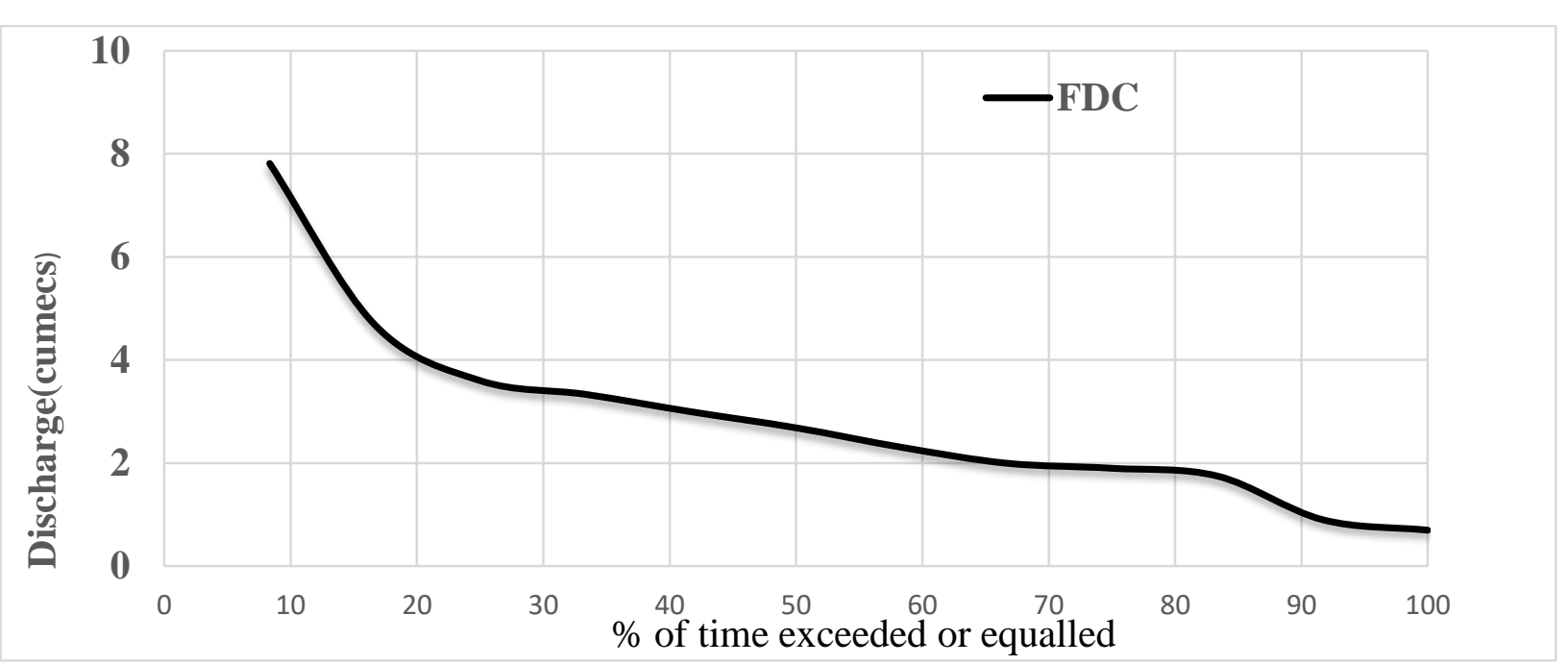

Figure 6: Flow duration curve of Huluka River

Table 3: Potential power calculation at variable discharge from Flow Duration Curve

\begin{tabular}{|l|l|c|c|c|c|}
\hline SN & \multicolumn{1}{|c|}{ Power types (KW) } & $\begin{array}{c}\text { Unit Weight of } \\
\text { water }(\mathbf{K N} / \mathbf{m 3})\end{array}$ & $\begin{array}{c}\text { variable discharge } \\
\text { read from FDC } \\
(\mathbf{m 3 / s})\end{array}$ & $\begin{array}{c}\text { Gross } \\
\text { head, } \\
\mathbf{h}(\mathbf{m})\end{array}$ & $\begin{array}{c}\text { Power } \\
(\mathbf{K W})\end{array}$ \\
\hline 1 & Minimum potential power & 9.81 & 0.7 & 39.96 & 274.40532 \\
\hline 2 & Small potential power & 9.81 & 0.7 & 39.96 & 274.40532 \\
\hline 3 & Average potential power & 9.81 & 2.5 & 39.96 & 980.019 \\
\hline 4 & Mean potential power & 9.81 & 2.886 & 39.96 & 1131.3339 \\
\hline 5 & Maximum potential power & 9.81 & 3.35 & 39.96 & 1313.2255 \\
\hline
\end{tabular}

Table 4: Potential power of Huluka River

\begin{tabular}{|l|l|l|l|l|l|l|l|l|l|l|l|l|}
\hline Month & Jan & Feb & Mar & Apr & May & Jun & Jul & Aug & Sep & Oct & Nov & Dec \\
\hline Q (m3/s) & 0.44 & 0.30 & 0.36 & 0.47 & 0.69 & 1.91 & 9.79 & 17.08 & 4.56 & 1.23 & 0.45 & 0.26 \\
\hline Head (m) & 40 & 40 & 40 & 40 & 40 & 40 & 40 & 40 & 40 & 40 & 40 & 40 \\
\hline Efficiency & 0.8 & 0.8 & 0.8 & 0.8 & 0.8 & 0.8 & 0.8 & 0.8 & 0.8 & 0.8 & 0.8 & 0.8 \\
\hline Power (KW) & 138.9 & 95.3 & 112.4 & 147.3 & 216.2 & 600.2 & 3074.5 & 5360.8 & 1431.1 & 386.9 & 140.3 & 80.8 \\
\hline
\end{tabular}




\section{Conclusion and Recommendation}

Based on the results of the study, the following conclusions are drawn:

The major failures of Huluka micro hydropower were due to siltation, overflowing of water, and lack of repair and maintenance of the structural components. It indicated a maximum annual average flow rate of $7.812 \mathrm{~m}^{3} / \mathrm{s}$, which shows a good potential rate. Hence, it is suggested the Ethiopian government should not rely solely on the development of large and medium scale hydropower, but it should be included the rehabilitation the existing and developing of the new Micro hydropower to help augment the power problem in the locality.

The status of all components of huluka micro hydropower scheme found out that it was still possible to restore and set into its function with little maintenance. Likewise, some other components need to redesign and replace.

\section{Acknowledgment}

The authors would like to thank Ambo University and mark a note of gratitude to Dr. Buzunesh Mideksa (Vice President for Research and Community Service, Ambo University), Dr Endrias Zewdu (Research Directorate Director, Ambo University) and Mr Woyesa Ararsa (Dean, Institute of Technology, Ambo University), for their help and continuous encouragement. The authors also grateful to the Sidama zone of SNNPR water, mines, and energy office, and GIZ Ethiopia, energy department office for their kind help and support during field survey and observation, including those who contributed to making this research paper to publish.

\section{References}

[1] A. W. Dametew, " Design and Analysis of mall Hydropower for Rural Electrification," Global Journal of Researches in Engineering (2016).

[2] D. M. Degefu, W. He and J. H. Zhao, " Hydropower for Sustainable water and Energy Development in Ethiopia," Springer (2015).

[3] M.o. W. a. E. Ethiopia, "Scaling-up Renewable Energy Programme" (2012).

[4] M. Shanko, " Target Market Analysis: Ethiopia's Small Hydro Energy Market, " pp. 409-415, 2009.

[5] Abebe (2011). Assessment of Micro-Hydropower Potential of Selected Ethiopia Rivers-A Case Study in the Northeast part of the Country.

[6] Dereje (2013). Ethiopia's Renewable Energy Power Potential and Development Opportunities. Ministry of Water and Energy, Abu Dhabi, UEA.

[7] Federal Democratic Republic of Ethiopia Ministry of Water Resources (2005). Anay River Basin Integrated Development Master Plan Study Project, Climatology, March 2005.

[8] Nardos, 2001. Upgrading of Mini-Hydropower plants (The case of Yadot Mini-Hydro power plant).

[9] V. Van der Zwaan et al.; Energy Strategy Reviews 19 (2018), 19-30. Prospect for Hydropower in Ethiopia: An Energy-Water Nexus Analysis.

*Corresponding author.

E-mail address: marcon4509@ gmail.com 